\title{
Determination of Total Phenolic Content of Nyirih Stem Bark Extract (Xylocarpus granatum J. Koeing) using UV-Vis Spectrophotometry Method
}

\author{
Aswar $^{1}$, Abd. Malik ${ }^{2}$, La Hamidu', Ahmad Najib ${ }^{2}$ \\ ${ }^{1}$ Division of Phytochemistry, Faculty of Pharmacy, Universitas Muslim Indonesia, Indonesia \\ ${ }^{2}$ Division of Pharmacognosy, Faculty of Pharmacy, Universitas Muslim Indonesia, Indonesia
}

\begin{tabular}{|c|c|}
\hline Article info & Abstract \\
\hline $\begin{array}{l}\text { History } \\
\text { Submission: } 23-10-2020 \\
\text { Review: } 11-01-2021 \\
\text { Accepted: } 24-02-2021\end{array}$ & $\begin{array}{l}\text { Nyirih is a plant from the Meliaceae family with the Latin name Xylocarpus } \\
\text { granatum J. Koeing. Nyirih spreads in tropical waters and does not cluster } \\
\text { in certain areas. This study aims to determine the total phenolic content of } \\
\text { the nyirih (Xylocarpus granatum J. Koeing) stem bark extract using the UV- }\end{array}$ \\
\hline $\begin{array}{l}\text { *Email: } \\
\text { ahmad.najib@umi.ac.id }\end{array}$ & $\begin{array}{l}\text { Vis spectrophotometric method. The stem bark extract of nyirih (Xylocarpus } \\
\text { granatum) was obtained by maceration with } 96 \% \text { ethanol solvent. } \\
\text { Determination of total phenolic content in the stem bark extract of nyirih }\end{array}$ \\
\hline DOI: $10.33096 /$ jffi.v8i3.728 & $\begin{array}{l}\text { (Xylocarpus granatum) is based on the Folin-Ciocalteau method, where the } \\
\text { addition of } 7 \% \text { sodium carbonate provides an alkaline atmosphere that will }\end{array}$ \\
\hline $\begin{array}{l}\text { Keywords: } \\
\text { nyirih stem bark (Xylocarpus } \\
\text { granatum J. Koenig), total } \\
\text { phenolic, folin-ciocalteau, UV- } \\
\text { Vis spectrophotometry }\end{array}$ & $\begin{array}{l}\text { produce phenolic ions. Furthermore, it will reduce Folin to form a blue } \\
\text { complex. At a maximum wavelength of } 755 \mathrm{~nm} \text {, the results showed that the } \\
\text { average total phenolic content of the stem bark extract of nyirih (Xylocarpus } \\
\text { granatum) was } 6.163 \mathrm{mg} G A E / g \text { of extract. }\end{array}$ \\
\hline
\end{tabular}

\section{Introduction}

Mangrove plants are one of the plants that can live in extreme environments, where the physical and chemical properties of their habitat are always changing as a result of the influence of tides, freshwater or rivers, silt deposition, decomposition of organic matter, and others. So that this plant has very good potential for research regarding secondary metabolite compounds it contains. Secondary metabolites are defined as compounds synthesized by organisms such as microbes, plants, insecticides, and so on. Not to comply their primary needs (to grow and develop) but to maintain their existence in interacting with their environment. Mangrove type Xylocarpus granatum J. Koeing has seeds, fruit, and tree bark which are useful as medicine for various types of diseases because they contain secondary metabolite compounds (Oktavianus, 2013).

The fruit peels of Xylocarpus granatum contain bioactive compounds that are useful and have economic value. Based on the phytochemical test, the simplicia of fruit peels contain flavonoids, tannins, saponins, hydroquinones, and steroids. Xylocarpus granatum has been used as a medicine for diarrhea, cholera, and wound cleansers. The oil from the seed extract mixed with rice flour is used as a mask to treat acne and the liquid oil is used to treat diarrhea. Xylocarpus granatum seeds contain tannins that have antibacterial properties. The seeds of Xylocarpus granatum have been used traditionally by coastal women as a traditional powder for skincare. The content of flavonoids, tannins, and saponins prevents the risk of skin hyperpigmentation due to exposure to ultraviolet radiation from sunlight. The phytochemical components in the bark and stem of Xylocarpus granatum did not differ between the bark and stem extract. Both consist of alkaloids, flavonoids, and tannins (Darusman, Batubara and Lopolisa, 2011; Riani, Zamani and Sulistiyani, 2013; Hendrawan, Zuraida and Pamungkas, 2015).

Flavonoids, tannins, lignins, anthraquinones, phenolic acids, and coumarin are phenolic compounds that are spread in plants in the form of simple phenols. Phenolic compounds have been known to have various biological effects, such as antioxidant activity through mechanisms as reducers, free radical scavengers, metal scavengers, absorbers of singlet oxygen formation, and electron donors (Karadeniz et al., 2005). Phenolic compounds are known to reduce the risk of cancer, coronary heart disease, stroke, atherosclerosis, osteoporosis, inflammation, and other neurodegenerative diseases (Surh, 2003)

Based on the description above, research was carried out on the total phenolic content contained in the stem bark extract of nyirih (Xylocorpus granatum) using the UV-Vis method to increase the scientific data of this plant, so that its role as a drug can produce effects that can be maximally enhanced and its use can be more accountable to the community. 


\section{Research Method \\ II.1 Sampling and Processing}

Samples of nyirih stem bark (Xylocorpus granatum) were taken at 08.00-11.00 hours obtained from Runaha District, South Kunawe Regency, Southeast Sulawesi Province. The stem bark of nyirih (Xylocorpus granatum) that had been taken were then dried by aerating. After drying, the sample was pollinated, then extracted by the maceration method.

\section{II.2 Extraction}

Nyirih stem bark (Xylocorpus granatum) 600 grams are put into the maceration vessel, then $3,500 \mathrm{ml}$ of $96 \%$ ethanol solvent is added. Left for 3 days in a closed vessel and protected from direct sunlight while stirring occasionally. After 3 days, it is filtered to obtain a liquid ethanol extract and the dregs are macerated again with a new filter liquid until it is clear. The extract obtained was then evaporated until a thick ethanol extract was obtained.

\section{II.3 Phytochemical Screening II.3.1 Flavonoid Test}

The extract of $1 \mathrm{~g}$ was added with $10 \mathrm{~mL}$ of methanol and $5 \mathrm{~mL}$ of petroleum ether, shaken and left to stand. The methanol layer evaporated at $40^{\circ} \mathrm{C}$. The remaining solution was added with $5 \mathrm{~mL}$ of ethyl acetate P, filtered. Then the test is carried out as follows:

1. One milliliter of test solution is evaporated to dryness, the rest is dissolved in 1-2 $\mathrm{mL}$ of ethanol $\mathrm{P}(96 \%)$, added with $0.5 \mathrm{~g}$ of zinc powder $\mathrm{P}$ and $2 \mathrm{~mL}$ of hydrochloric acids $2 \mathrm{~N}$, left to stand for 1 minute. 10 drops of concentrated chloride acid are added. If an intensive red color is formed, it indicates the presence of flavonoids (glycosides-3-flavonol).

2. The test solution of $1 \mathrm{~mL}$ is evaporated, the remainder is dissolved in $1 \mathrm{~mL}$ of ethanol $\mathrm{P}$ (95\%), $0.1 \mathrm{~g}$ of magnesium $\mathrm{P}$ powder is added and 10 drops of hydrochloric acid $P$. If there is a red-orange to red-purple color, this indicates flavonoids. If the yellow color indicates the presence of flavonoids.

\section{II.3.2 Tannins}

One gram of extract was added to $15 \mathrm{ml}$ of hot water. The solution is heated to boiling for 5 minutes, filtered. Five milliliters of filtrate is added with a few drops of $\mathrm{FeCl}_{3} 1 \%$, resulting in a violetgreen color. The filtrate of $5 \mathrm{~mL}$ is added with gelatin $10 \%$ to form a white precipitate. Five milliliters of filtrate is added with $\mathrm{NaCl}$-gelatin $(1 \%$ gelatin solution in $10 \% \mathrm{NaCl}$ solution) to form a white precipitate.

\section{II.4 Quantitative Analysis of Phenolic content II.4.1 Preparation of $\mathrm{Na}_{2} \mathrm{CO}_{3} 7 \%$ Reagent Weighed as much as 3.5 grams of $\mathrm{Na}_{2} \mathrm{CO}_{3}$ then dissolved in sterile aquadest up to $50 \mathrm{ml}$.}

\section{II.4.2 Determination of Total Phenolic Content} Preparation of standard solution of gallic acid

A standard solution of $1000 \mathrm{ppm}$ gallic acid is prepared by weighing $10 \mathrm{mg}$ of gallic acid diluted with methanol p.a up to $10 \mathrm{~mL}$. From the stock solution pipette as much as $1 \mathrm{~mL}$ diluted with methanol p.a up to $10 \mathrm{~mL}$ to produce a concentration of $100 \mathrm{ppm}$, then made concentrations of $0.2,0.4$, $0.6,0.8$, and $1 \mathrm{ppm}$.

\section{Measurement of Gallic Acid Standard Solution}

For each concentration of $0.2,0.4,0.6,0.8$, and $1 \mathrm{ppm}$ added with $0.4 \mathrm{~mL}$ of Folin-Ciocalteau reagent, shaken and left for 4-8 minutes, add $4.0 \mathrm{~mL}$ of $\mathrm{Na}_{2} \mathrm{CO}_{3} 7 \%$ solution, shake until homogeneous. Add up to $10 \mathrm{~mL}$ of sterile distilled water and let stand for 2 hours at room temperature. Measure the absorption at a maximum wavelength of $755 \mathrm{~nm}$, then make a calibration curve for the relationship between the concentration of gallic acid $(\mu \mathrm{g} / \mathrm{mL})$ and the absorbance.

\section{Preparation of a sample solution for the extract of nyirih stem bark (Xylocarpus granatum).}

Weighed $10 \mathrm{mg}$ of Nyirih stem bark extract, then dissolved in $10 \mathrm{~mL}$ ethanol.

\section{Determination of total phenolic content of nyirih wood extract (Xylocarpus granatum)}

A pipette as much as $0.5 \mathrm{~mL}$ of solution from the stem bark extract of nyirih (Xylocarpus granatum). Added with $0.4 \mathrm{~mL}$ of Folin-Ciocalteau reagent, shaken and left for 4-8 minutes, add $4.0 \mathrm{~mL}$ of $\mathrm{Na}_{2} \mathrm{CO}_{3} 7 \%$ solution, shake until homogeneous. Add up to $10 \mathrm{~mL}$ of sterile distilled water and let stand for 2 hours at room temperature. Measure the absorption at the maximum absorption wavelength of $755 \mathrm{~nm}$ which will give the blue complex. Make 3 repetitions. The results are expressed as $\mathrm{mg}$ gallic acid equivalent/g of extract.

\section{Results and Discussion}

The sample used in this study was nyirih stem bark from Kunaha District, South Kunawe Regency, Southeast Sulawesi Province. Nyirih stem bark was then determined at the PharmacognosyPhytochemical Laboratory of the Faculty of Pharmacy, UMI to ensure the correctness of the plant material used, the results of the determination indicated that the sample was Xylocarpus granatum from the Meliaceae family.

To obtain the stem bark extract of nyirih (Xylocarpus granatum), the method used is maceration. The results obtained from the extraction method can be seen in Table 1 . 
Table 1. The yield results of the stem bark extract of Nyirih (Xylocarpus granatum)

\begin{tabular}{lllll}
\hline Solvent & $\begin{array}{l}\text { Solvent Volume } \\
(\mathbf{m L})\end{array}$ & $\begin{array}{l}\text { Sample Weight } \\
(\mathbf{g})\end{array}$ & $\begin{array}{l}\text { Extract Weight } \\
(\mathbf{g})\end{array}$ & Rendemen $(\%)$ \\
\hline Ethanol $96 \%$ & 3500 & 650 & 52,88 & 8,1353 \\
\hline
\end{tabular}

The maceration method is used because it can reduce the damage to the compounds contained in the sample due to heating and does not require special tools. The solvent maceration method used is $96 \%$ ethanol because it is mostly used in the isolation process of natural organic compounds which can dissolve almost all secondary metabolites, so that a liquid ethanol extract is obtained which is then evaporated using a rotary evaporator and a thick ethanol extract of 52.88 grams is obtained. Percent rendemen is $8.1353 \%$.
The yield percentage was determined to determine the levels of secondary metabolites carried by the solvent but could not determine the type of compound carried (Ukieyanna, Suryani and Roswiem, 2012).

The identification of the compounds contained in Nyirih stem bark was carried out by phytochemical screening, while the results obtained can be seen in Table 2 and Figure 1.can be seen in Table 2 and Figure 2.

Table 2. The results of the phytochemical screening of the stem bark extract of Nyirih (Xylocarpus granatum)

\begin{tabular}{|c|c|c|c|c|}
\hline Sample & $\begin{array}{l}\text { Chemical } \\
\text { Identification }\end{array}$ & Reagent & Result & Information \\
\hline \multirow[t]{5}{*}{$\begin{array}{l}\text { Nyirih stem bark } \\
\text { extract }\end{array}$} & \multirow[t]{2}{*}{ Flavonoid } & $\begin{array}{l}\text { Zinc powder } \mathrm{p}+ \\
\text { HCL }\end{array}$ & Red & $\begin{array}{l}\text { Positive (Adline and Devi, } \\
\text { 2014) }\end{array}$ \\
\hline & & $\begin{array}{l}\text { Magnesium + } \\
\text { HCL P }\end{array}$ & Yellow-Orange & $\begin{array}{l}\text { Positive (Apsari and Susanti, } \\
\text { 2011) }\end{array}$ \\
\hline & \multirow[t]{3}{*}{ Tanin } & $\mathrm{FeCl}_{3} 1 \%$ & Green & $\begin{array}{l}\text { Positive (Farnsworth, 1996; } \\
\text { Sangi et al., 2008) }\end{array}$ \\
\hline & & Gelatin $10 \%$ & White sediment & $\begin{array}{l}\text { Positive (Trease and Evans, } \\
\text { 1978; Geetha and Geetha, } \\
\text { 2014) }\end{array}$ \\
\hline & & $\mathrm{NaCl}$-gelatin & White sediment & $\begin{array}{l}\text { Positive (Trease and Evans, } \\
\text { 1978; Geetha and Geetha, } \\
\text { 2014) }\end{array}$ \\
\hline
\end{tabular}

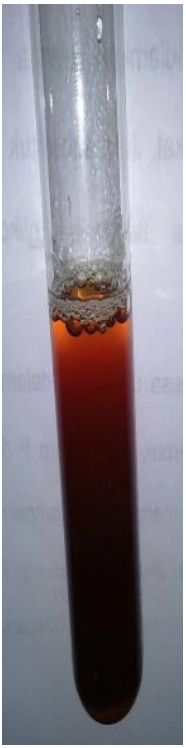

A

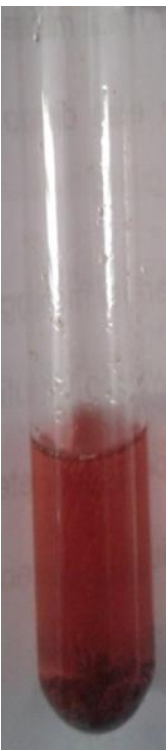

B

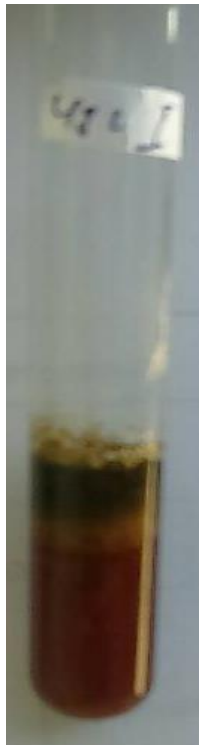

C

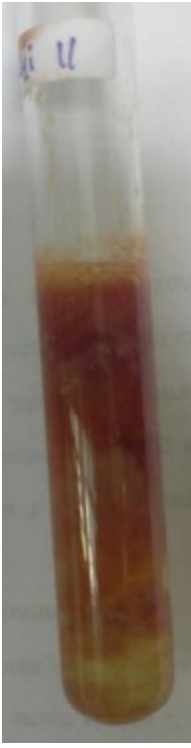

D

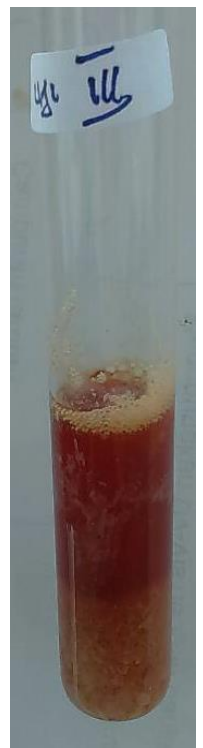

$\mathrm{E}$

Figure 1. The results of the phytochemical screening of the stem bark extract of nyirih Note: A (Zinc powder p + HCL); B (Magnesium + HCL P); C $\left(\mathrm{FeCl}_{3} 1 \%\right)$; D (Gelatin $\left.10 \%\right)$; and E (NaCl-gelatin) 
The results of phytochemical screening tests showed that the positive compounds in the ethanol extract were flavonoids and tannins. Where the positive results of flavonoids in the reagent test for zinc powder $\mathrm{p}$ and HCL were marked with a red color change and in the magnesium reagent test added HCL $\mathrm{P}$ was marked with a yellow-orange color change. While the positive result of tannins in the $1 \% \mathrm{FeCl}_{3}$ test is indicated by a change in green color. In the gelatin 10 and $\mathrm{NaCl}$-gelatin reagent test, there was marked sediment.

Furthermore, a qualitative analysis was carried out using the Folin-Ciocalteau method (Chun, Kim and Lee, 2003) to determine the total phenolic content in the extract of nyirih stem bark, and as a standard used a solution of gallic acid or 3,4,5-trihydroxybenzoic acid $\left(\mathrm{C}_{6} \mathrm{H}_{2}(\mathrm{OH})_{3} \mathrm{CO}_{2} \mathrm{H}\right)$ (Apsari and Susanti, 2011).

The principle of the folin-ciocalteau method is the formation of complex blue compounds that can be measured at certain wavelengths (Apsari and Susanti, 2011). This method is the most commonly used method to determine the total phenolic content in plants with the consideration that this technique is cheaper and simpler (Mariska, 2009). Folin-Ciocalteau contains a mixture of sodium tungstate, sodium molybdate, lithium sulfate, concentrated hydrochloric acid, 85\% phosphoric acid, bromine, and distilled water. The Folin-Ciocalteau reagent is used because phenolic compounds can react with folin to form a colored solution whose absorbance can be measured. This reagent oxidizes phenolics (alkaline salts) or phenolic-hydroxy groups to reduce heteropoly acids (phosphomolybdate-phosphotungstate) found in Folin-Ciocalteau reagent to become a molybdenumtungsten complex. The addition of $\mathrm{Na}_{2} \mathrm{CO}_{3} 7 \%$ aims to create alkaline conditions for proton dissociation in phenolic compounds into phenolic ions (Lim and Murtijaya, 2007).

In this study, gallic acid was used to determine the total phenolic compound in the sample as a standard solution. Gallic acid is used as a standard solution because it is a natural and stable phenol, and is relatively inexpensive compared to others. Gallic acid is included in phenolic compounds, hydroxybenzoic acid derivatives which are classified as simple phenolic acids. Gallic acid has become the standard for the availability of stable and pure substances. Gallic acid is reacted with the folin-ciocalteau reagent to produce a yellow color which indicates that it contains phenol, after which it is added with $\mathrm{Na}_{2} \mathrm{CO}_{3}$ solution to produce a blue color (Mariska, 2009). Gallic acid standard solution was measured with various concentrations of 0.2 , $0.4,0.6,0.8$, and $1 \mathrm{ppm}$ at a maximum wavelength of $755 \mathrm{~nm}$ (Table 3 ).

Table 3. The results of the absorbance measurement of gallic acid

\begin{tabular}{ll}
\hline Concentration $(\mathbf{m g} / \mathbf{L})$ & Absorbance \\
\hline $0,2 \mathrm{ppm}$ & 0,152 \\
$0,4 \mathrm{ppm}$ & 0,240 \\
$0,6 \mathrm{ppm}$ & 0,316 \\
$0,8 \mathrm{ppm}$ & 0,362 \\
$1,0 \mathrm{ppm}$ & 0,532 \\
\hline
\end{tabular}

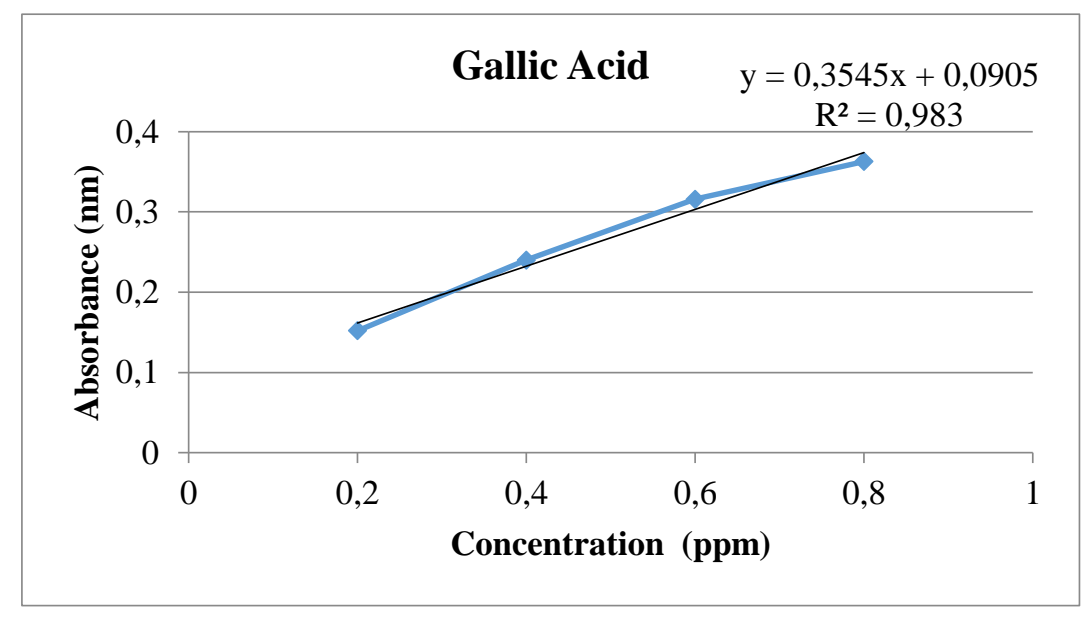

Figure 2. Gallic acid calibration curve at a wavelength of $755 \mathrm{~nm}$

The results of the comparative measurement of gallic acid are plotted on their concentration so that a curve is obtained as shown in Figure 2. The $\mathrm{R}^{2}$ value of 0.983 indicates good linearity. Then the linear regression equation $(y=$ $0.3545 \mathrm{x}+0.0905$ ) can be used to determine the total phenolic content of the nyirih stem bark extract. 
Table 4. The results of the determination of the total phenolic content of the nyirih stem bark (Xylocarpus granatum) extract

\begin{tabular}{lllll}
\hline Replication & $\begin{array}{l}\text { Absorbance } \\
(\mathbf{y})\end{array}$ & $\begin{array}{l}\text { Initial Total } \\
\text { Phenolic Content } \\
\text { (mgGAE/L) }\end{array}$ & $\begin{array}{l}\text { Total Phenolic } \\
\text { Content (mgGAE/g) }\end{array}$ & $\begin{array}{l}\text { Average Total Content } \\
\text { (mgGAE/g) }\end{array}$ \\
\hline I & 0,322 & $0,6530 \mathrm{mg} / \mathrm{L}$ & $6,53 \mathrm{mg} \mathrm{GAE} / \mathrm{g}$ & $6,163 \mathrm{mg} \mathrm{GAE} / \mathrm{g}$ \\
II & 0,285 & $0,5486 \mathrm{mg} / \mathrm{L}$ & $5,486 \mathrm{mg} \mathrm{GAE} / \mathrm{g}$ & \\
III & 0,320 & $0,6473 \mathrm{mg} / \mathrm{L}$ & $6,473 \mathrm{mg} \mathrm{GAE} / \mathrm{g}$ & \\
\hline
\end{tabular}

The total phenolic content in plants is expressed in GAE (Galic Acid Equivalent), which is the equivalent of milligrams of gallic acid in 1 gram of sample (Ratnayani, Laksmiwati and P, 2012). Three replications were made for the measurement of total phenolic compounds for data acculturation purposes. So that the results of this study obtained the total phenolic content of the stem bark extract of nyirih (Xylocarpus granatum), which is $6.163 \mathrm{mg}$ $\mathrm{GAE} / \mathrm{g}$.

\section{Conclusions}

Based on the results of the research conducted, it can be concluded that the stem bark extract of nyirih (Xylocarpus granatum J. Koeing) contains phenolic compounds of $6.163 \mathrm{mg} \mathrm{GAE} / \mathrm{g}$.

\section{References}

Adline, J. and Devi, A. (2014) 'A Study On Phytochemical Screening And Antibacterial Activity Of Moringa oleifera', International Journal of Research in Applied, Natural and Social Sciences (IMPACT: IJRANSS), 2(5), pp. 169-176.

Apsari, P. D. and Susanti, H. (2011) Perbandingan Kadar Fenolik Total Ekstrak Metanol Kelopak Merah dan Ungu Bunga Rosella (Hibiscus sabdariffa Linn) secara spektroftometri. Yogyakarta: Kerjasama Fakultas Farmasi dan Fakultas Kesehatan Masyarakat Universitas Ahmad Dahlan.

Chun, O. K., Kim, D.-O. and Lee, C. Y. (2003) 'Superoxide Radical Scavenging Activity Of The Major Polyphenols In Fresh Plums', Journal of Agricultural and Food Chemistry, 51(27), pp. 8067-8072. doi: 10.1021/jf034740d.

Darusman, L. K., Batubara, I. and Lopolisa, C. (2011) 'Screening Marker Components Of Tyrosinase Inhibitor From Xylocarpus Granatum Stem', Jurnal Kimia Valensi, 2(3), pp. 409-413. doi: 10.15408/jkv.v2i3.111.

Farnsworth, N. R. (1996) 'Biological And Phytochemical Screening Of Plants', Journal Pharmaceutical Sciences, 55(3), pp. 225-276. doi: 10.1002/jps.2600550302.

Geetha, T. S. and Geetha, N. (2014) 'Phytochemical Screening, Quantitative Analysis Of
Primary And Secondary Metabolites of Cymbopogan citratus (DC) Stapf. Leaves From Kodaikanal Hills, Tamilnadu', International Journal of PharmTech Research, 6(2), pp. 521-529.

Hendrawan, Zuraida, I. and Pamungkas, B. F. (2015) 'Aktivitas Antibakteri Ekstrak Metanol Xylocarpus granatum Dari Pesisir Muara Badak', Jurnal Ilmu Perikanan Tropis, 20(2), pp. 015-022.

Karadeniz, F. et al. (2005) 'Antioxidant Activity of Selected Fruits and Vegetables Grown in Turkey', Turkish Journal of Agriculture and Forestry, 29(4), pp. 297-303.

Lim, Y. Y. and Murtijaya, J. (2007) 'Antioxidant Properties of Phyllanthus amarus Extracts As Affected By Different Drying Methods', LWT - Food Science and Technology, 40(9), pp. 1664-1669. doi: 10.1016/j.lwt.2006.12.013.

Mariska, V. P. (2009) Pengujian Kandungan Senyawa Yang Terdapat Dalam Tomat (Lycopersicum esculentum) Secara In Vitro. Universitas Indonesia.

Oktavianus, S. (2013) Uji Daya Hambat Ekstrak Daun Mangrove Jenis Avicennia marina Terhadap Bakteri Vibrio parahaemolyticus. Universitas Hasanuddin.

Ratnayani, K., Laksmiwati, A. A. I. . M. and P, N. P. I. S. (2012) 'Kadar Total Senyawa Fenolat Pada Madu Randu Dan Madu Kelengkeng Serta Uji Aktivitas Antiradikal Bebas Dengan Metode Dpph (Difenilpikril Hidrazil)', Jurnal Kimia, 6(2), pp. 163168.

Riani, E., Zamani, N. P. and Sulistiyani (2013) Potensi Sumberdaya Mangrove sebagai Sumber Bahan Baku Biofarmaka Baru untuk Penyakit Non Infeksius Manusia. Direktorat Jenderal Pendidikan Tinggi. Departemen Pendidikan Nasional.

Sangi, M. et al. (2008) 'Analisis Fitokimia Tumbuhan Obat Di Kabupaten Minahasa Utara', Chemistry Progress, 1(1), pp. 4753. doi: 10.35799/cp.1.1.2008.26.

Surh, Y.-J. (2003) 'Cancer Chemoprevention with Dietary Phytochemicals', Nature Reviews Cancer, 3(10), pp. 768-80. doi: 10.1038/nrc1189. 
Trease, G. E. and Evans, W. C. (1978) Pharmacognosy. 11th edn. London: Bailliere Tindall.

Ukieyanna, E., Suryani and Roswiem, A. P. (2012) Aktivitas Antioksidan, Kadar Fenolik, dan Flavonoid Tumbuhan Suruhan (Peperomia pellucida L. Kunth). Institut Pertanian Bogor. 